\title{
KEEPING WOOLF FROM THE DOOR - THE REFORM OF CIVIL PROCEDURE IN NORTHERN IRELAND
}

\author{
David Capper, Senior Lecturer in Law, Queen's University of \\ Belfast
}

\section{INTRODUCTION}

Problems of cost, complexity and delay have bedevilled the civil courts of England and Wales for decades. The final report of Lord Woolf's review of the civil justice system ${ }^{1}$ was the latest of 60 reports on the same subject dating back to 1851 . Since 1921 Northern Ireland has had five reports concerned wholly or in part with civil procedure and the organisation of the civil courts. ${ }^{2}$ To these must now be added the Interim Report of the Civil Justice Reform Group (hereafter the Interim Report), whose proposals will be the subject of comment in the present article.

The Civil Justice Reform Group was set up on 21 February 1998 with the following task:-

"To review procedures in Northern Ireland for the administration of civil justice, and produce, for consultation with interested parties, recommendations as to how the civil justice system could be developed so as to make it as accessible, economical and efficient as possible." 3

In doing this the Group was to have regard to the recommendations made in the report of Lord Woolf and the review conducted in the summer and early autumn of 1997 by Sir Peter Middleton. ${ }^{4}$

Lord Woolf's report recommended radical reform of the way in which civil cases were conducted. The proposed reforms largely came into force on 26 April 1999 when the Civil Procedure Rules 1998, which replaced the former Supreme Court Rules and the County Court Rules, came into force. These rules establish three different tracks for civil cases depending on their complexity and the value of the case. Cases valued up to $£ 5,000$ are determined on a small claims track; cases valued above $£ 5,000$ but not above $£ 15,000$ go to a fast track; and cases valued above $£ 15,000$ are determined on a multi-track. The small claims track is essentially an expanded version of the Small Claims Court which previously had jurisdiction to determine disputes valued up to $£ 3,000$. The fast track operates on the basis of a fixed timetable of 30 weeks with limited

1 Lord Woolf, Access to Justice: Final Report to the Lord Chancellor on the civil justice system of England and Wales (London, HMSO, 1996).

2 The report of the Shiel Committee, Report of the Committee on the Supreme Court of Northern Ireland (1957); the MacDermott Committee, Report of the Committee on the Supreme Court of Judicature of Northern Ireland (1970); the Lowry Committee, Interim Report of the Joint Committee on Civil and Criminal Jurisdiction in Northern Ireland (1973); the Jones Commission, Report of Committee on County Courts and Magistrates' Courts in Northern Ireland (1974); Courts in Northern Ireland - The Future Pattern (1977) - the Government's response to the three previous reports.

3 See the speech of the Lord Chancellor, the Right Honourable Lord Irvine of Lairg, to the first Bar of Northern Ireland conference on 21 February 1998.

4 A Review of Civil Justice and Legal Aid (October 1997). 
discovery and limited scope for other interlocutory matters. The multitrack is intended to provide a flexible system for matching the procedure to be adopted to the value, importance and complexity of the dispute. The central feature of the multi-track, and the fast track to a lesser extent, is the provision for judicial case management of proceedings. Parties are no longer to be trusted with the management of civil litigation themselves. Instead they must attend hearings before a procedural judge who has power to determine what steps shall be taken to get the case ready for trial and to lay down a timetable for taking those steps. There is no coincidence between the County Court or the High Court with either the fast track or the multi-track, both courts retaining their independence and the upper limit on the monetary jurisdiction of the County Court remaining at $£ 50,000$.

For Northern Ireland, the Civil Justice Reform Group (hereafter the "Group") accepted some of the Woolf reforms but rejected others. It accepted the first of the two main tenets of the Woolf Report, the three track system, but in a substantially reduced and modified form. What is proposed is a three tiered system, consisting of the Small Claims Court, the County Court and the High Court. Unlike England and Wales there is an exact coincidence between tiers and courts, with $£ 15,000$ representing the dividing line between the middle tier (County Court) and upper tier (High Court) and $£ 2,000$ forming the boundary between the Small Claims Court and the County Court. The second main tenet, judicial case management, is almost completely rejected apart from the proposal to introduce to the High Court a system akin to the Certificate of Readiness system currently operating in the County Court. Many of the more specific recommendations of the Woolf Report were considered, some being accepted in part and others rejected. The general philosophy of the Interim Report is clearly Woolf sceptic and aims to preserve as much of the current system as appears to be working well. The author believes this general approach to be a wise one but also one which fully justifies the slightly irreverent title to this article.

The Interim Report was published in April 1999 and requested consultees to deliver their submissions to the Group by 25 June 1999 . The author should immediately declare that he has contributed to the preparation of some of the comments which have already been passed to the Group. This article is written to set out the author's own individual views with the aim of contributing further to the debate on this important subject. There will not be much divergence from the views expressed by other bodies with which the author has been associated, but nothing in this article should be understood as representing the views of anyone apart from the author.

The article sub-divides the proposals of the Interim Report into five sections and offers commentary upon each. The first section deals with the Small Claims Court, the second with the County Court, the third with the High Court, the fourth with the conduct of litigation in both the County Court and the High Court, and the fifth with the development of civil justice policy. Commentary will not be provided on every proposal made in the Interim Report as that would be an exhausting and not particularly productive undertaking. Instead the layout and shape of the civil justice system of Northern Ireland, as the Interim Report conceives it, will be subjected to analysis.

\section{THE SMALL CLAIMS COURT}

The Civil Justice Reform Group made an extensive series of recommendations relating to the Small Claims Court. First they recommended that the monetary limit on the jurisdiction of the court in 
Northern Ireland be raised from $£ 1,000$ to $£ 2,000$. With regard to the types of claim which can be brought to the Small Claims Court the Group came to no fixed conclusion on whether personal injury cases should continue to be excluded but was definite that claims arising from road traffic accidents should not be litigated there. The existing list of "excepted proceedings" contained in Order 25, Rule 15(1) of the County Court Rules (Northern Ireland) ${ }^{5}$ was left untouched and it was further recommended that in small claims the District Judge should not be given power to issue injunctions or orders for specific performance. Several recommendations were made with respect to pre-hearing procedure. These included permitting proceedings to be served out of the jurisdiction, introducing a default judgment power, allowing the removal of small claims to the County Court, and preserving the present rules dispensing with pleadings and discouraging interlocutory motions. In relation to procedure at hearing the Group recommended very little change. The current disapplication of the usual rules of evidence was supported. The Group was undecided on the circumstances in which expert evidence should be allowed, setting out four options ranging from a complete ban to unrestricted use. Where it is allowed the Group recommended that it should come in the form of a written report, with oral testimony only being permitted at the discretion of the District Judge. Legal representation should continue to be permitted and the right of litigants to be represented by lay advisers, normally allowed in practice, should be statutorily confirmed. The Group also recommended a new right of appeal to the County Court against a small claims decision. With regard to costs the Group recommended that the "no costs" rule should continue but that the court fees for using the small claims procedure and the costs of enforcing a small claims award should be examined to see whether they are too high.

These proposals differ from the small claims track operating in England and Wales in several very material particulars. Most important is probably the very much lower monetary limit on the jurisdiction of the Small Claims Court, but also important are the refusal to accept that claims arising out of road traffic accidents are appropriate for this forum and the absence of any positive recommendation to include personal injury claims. Much of the Group's analysis of the Small Claims Court is both thorough and thoughtful and the majority of its recommendations should be accepted. But despite these positives the Interim Report lacks an overall conception of what purpose a Small Claims Court should serve. Perhaps a committee dominated by judges and practising lawyers inevitably would have difficulty with a task of this kind. Reading between the lines there appears to be an almost grudging acceptance that there is a separate procedure for low value claims but that the bar (monetary limit) should be set as low as possible. Some of the recommendations which should be accepted are better justified on grounds different from those the Group relied upon.

The author's preferred conception of a small claims procedure is one where consumers can litigate claims or defend proceedings brought against them in an informal atmosphere where they do not need to be represented by a lawyer. The Interim Report's failure to grasp this concept is most clearly seen in its statement that the Group is unaware of any evidence to suggest that individual members of the public are not fully

5 These cover actions for libel or slander; actions for the recovery of legacies, annuities or gifts to charity; proceedings in relation to title to land; proceedings under section 17 of the Married Women's Property Act 1882; and cases remitted from the High Court. 
utilising the current procedure and in its failure to make any substantive proposals to raise publicity about the Small Claims Court. ${ }^{6}$ Unhappily there is evidence of under-utilisation of the small claims procedure. In an unpublished report for the General Consumer Council for Northern Ireland in 1998, Coopers and Lybrand found that only $21 \%$ of those surveyed knew anything about the Small Claims Court; $66 \%$ had heard of it but knew nothing about it; and the remainder had never heard of it. ${ }^{7}$ Other indications of the Group's slightly blinkered approach to the concept of a small claims court include its failure to consider what kinds of help with small claims are available for litigants and what is needed in this area; the proposal for a default judgment procedure; and the failure to address any arguments in support of the banning of lawyers from the Small Claims Court. These issues will be addressed in more detail below where it will be seen that sometimes the Group's recommendations should be accepted anyway, albeit for reasons different from those given.

The Group was correct to recommend that the monetary limit on the jurisdiction of the Small Claims Court be increased from $£ 1,000$ to $£ 2,000$ but no further for the meantime. The best reason for this is that in the absence of recent detailed research into the operation of the Small Claims Court there would be no way of predicting the consequences of a dramatic increase in the monetary limit. The last such research was the General Consumer Council's 1992 publication How to Make Small More Beautiful and occurred around the time when the small claims limit was raised from $£ 500$ to $£ 1,000$. The risks involved in a too drastic increase in the monetary limit are that many people would be compelled to litigate cases in a forum where Legal Aid is unavailable; it is unknown to what extent alternative forms of assistance such as those provided by the voluntary advice sector could cope; and costs could not be recovered where a litigant felt compelled to engage the services of a solicitor. There is clearly nothing like the need that existed in England and Wales to increase the monetary limit more significantly. The system of fixed legal costs in the County Court ensures that the cost of litigation in Northern Ireland is both lower and more predictable than in England and Wales. The horrifying picture presented by Professor Baldwin of County Court litigants in England and Wales incurring costs significantly in excess of the value of the claim is unlikely to be replicated in Northern Ireland. ${ }^{8}$ However this is not to say that an expanded Small Claims Court could not offer real advantages, particularly in terms of speed and informality, but it is to say that the way forward should be a cautious one which places a high premium on monitoring and ascertaining the consequences of increases in the monetary limit.

With regard to the kinds of claim which can be brought to the Small Claims Court it is submitted that personal injury cases should only be brought to this forum where the plaintiff wishes to do so. Negligence is difficult to prove unless the litigator has some practical experience and many litigants in person might not even understand the need to prove that someone was at fault and that this caused the injuries they suffered. The risk of litigants without trained assistance being outgunned by claims managers acting for insurance companies is too great to make this a

6 See Interim Report, para 7.34.

7 Consumer Rights and Redress Study (unpublished report for the General Consumer Council for Northern Ireland by Coopers and Lybrand, 1998) pp 2324.

8 See J. Baldwin, Monitoring the Rise of the Small Claims Limit: Litigants' Experiences of Different Forms of Adjudication (Lord Chancellor's Department Research Series no. 1/97). 
compulsory process. Claims for property damage arising out of road traffic accidents should continue to be excluded in the light of the English experience with this process. There it is quite clear that insurance companies have been abusing the small claims procedure to get quick and cheap decisions on liability to govern issues of great importance, such as which company must pay compensation for personal injuries and which driver's "no claims" bonus will be lost. It was wise to recommend keeping the "excepted proceedings" out of the Small Claims Court and to preserve the current restriction on injunctions and specific performance as the issues involved in these proceedings are too important for a procedure so informal.

The pre-hearing procedure recommendations contain a mixture of good and bad. Good is the recommendation to allow small claims proceedings to be served out of the jurisdiction. At present where a consumer has a claim against a mail order company or a tour operator based outside Northern Ireland the case has to be taken to the jurisdiction where the defendant is situated. Good also are the recommendations to allow removal of a small claim to the District Judge's civil bill list, either on the application of a party or of the judge's own motion, and the preservation of the principles disposing of pleadings and discouraging interlocutory motions. Less good is the proposal to introduce a default judgment procedure to the Small Claims Court. Vulnerable litigants are frequently defendants and it provides a measure of protection to them if the plaintiff (more often than not a business) has to come to court and prove the case anyway. The problem giving rise to the recommendation for default judgments, that of litigants with contested cases having to wait around all day while the uncontested ones are processed first, could be better solved by having separate listings for defended and undefended cases, as is the current practice in the County Court.

In relation to the hearing the first issue to tackle concerns expert witnesses. Here the Group was clearly concerned to ensure that experts could assist the decision making process without their use becoming disproportionate to the complexity of the issues or the amount in dispute. The proposal that expert witnesses should generally give their evidence in the form of a written report and only be permitted to give oral evidence with the leave of the judge can be supported as an attempt to maintain a sensible balance between these considerations. As to when expert witnesses should be allowed, the two extremes of "never" and "unrestricted use" are plainly inconsistent with the objective just stated so some in-between position should be sought. The proposal that this be either on the direction of the court or with the agreement of all parties appears to be the most appropriate one. The question of representation raises one relatively uncontentious issue and another very contentious one. The uncontentious one is the proposal to give statutory recognition to the right of a litigant to be represented by a lay adviser. This happens quite frequently at present but the increase and prospect of further increases in the monetary limit of the jurisdiction of the Small Claims Court is likely to create greater need for lay representation so clarification of this issue is clearly desirable. The contentious issue concerns whether professional lawyers should be barred from the Small Claims Court altogether. The Interim Report gives a fairly emphatic "no" to this question, citing the probable wishes of some litigants to be represented by a lawyer and a possible infringement of the European Convention on Human Rights as reasons why this would be inappropriate. A reason why it would be inappropriate at present is that a heavy burden might then be placed on the voluntary advice sector to fill the gap vacated by lawyers before this sector 
is sufficiently funded and otherwise ready to assume this role. ${ }^{9}$ However it is somewhat disappointing that the Interim Report never enters into the debate which has gone on in several countries as to whether professional lawyers should be barred from such tribunals. Reference is made to Professor Baldwin's research to justify a role for lawyers in giving prehearing advice to litigants but his reference to the debate just mentioned is not even acknowledged. ${ }^{10}$ Failure to do so is indicative of a lack of vision as to how the Group saw the Small Claims Court developing in the future and its overall role in the civil justice system.

The remaining recommendations can be discussed relatively briefly. First of all it is welcome that a real right of appeal against decisions of the Small Claims Court has been recommended. The present appeal to the High Court on a point of law offers virtually nothing ${ }^{11}$ so the proposal both to make this to the County Court and on the additional ground of serious irregularity of procedure should be supported. It would be going too far for disputes of this nature to make the right of appeal as extensive as that from the County Court to the High Court but the proposal to require leave from the District Judge could be problematic. Few would take exception to the suggestion that they had made an error of law but serious irregularity of procedure is another matter. It would be better if leave had to be sought from a County Court judge. In relation to fees the Group was correct to challenge the apparent lack of proportionality between the fees charged to litigants and the amount of money involved, both in relation to fees charged for litigating a claim and for the enforcement of an award. As far as enforcement is concerned current fees for small judgments are startlingly out of line with the recommendations of the Anderson Committee whose work laid the foundations of the Northern Ireland enforcement of judgments system. ${ }^{12}$ In fact enforcement of judgments generally is a subject neglected by the entire civil justice review project, as much by the Group's terms of reference as anything else. It is long past the time when the many recommendations of the Hunter Committee for the improvement of this system were implemented. ${ }^{13}$

9 Two recent publications bear testimony to the very fragmented funding arrangements which the voluntary sector is subject to. See The Community Legal Service (Lord Chancellor's Department consultation paper, May 1999); L. Lundy and S.R. Glenn, Advice Services in Northern Ireland (report for the Lord Chancellor's Legal Aid Advisory Committee for Northern Ireland, June 1999).

10 See J. Baldwin, Monitoring the Rise of the Small Claims Limit: Litigants' Experiences of Different Forms of Adjudication (Lord Chancellor's Department Research Series no. 1/97) at p 76 where the author states - "[t]his question is the subject of a vigorous debate that continues to preoccupy commentators in other jurisdictions, some of whom argue that legal representation causes needless expense to litigants, that it changes the informal character of proceedings, and that it favours the wealthy who are usually well placed to take care of themselves. It is surely time the same question was raised here too."

11 See D.S. Greer, "Challenging a Small Claims Award" (1987) 30 NILQ 79.

12 See Report of the Joint Working Party on the Enforcement of Judgments, Orders and Decrees of the Courts of Northern Ireland (Belfast, HMSO, 1966) para 53 where an enforcement fee exceeding $5 \%$ of the amount recoverable was only recommended for judgments in the $£ 20-50$ bracket. Contrast the current position where enforcement fees do not get below $10 \%$ until well into the $£ 3,000-10,000$ bracket and do not fall below 5\% until $£ 15,000$ is reached.

13 See Report of the Enforcement of Judgments Review Committee (Northern Ireland) (Belfast, HMSO, 1987). 


\section{THE COUNTY COURT}

Measured against the triple cocktail of cost, complexity and delay the County Court in Northern Ireland does not present serious problems. Costs are controlled by the fixed scale costs in the County Court Rules (Northern Ireland), these being much lower as well as more predictable than the billing by the hour which has caused so many problems in England and Wales. The civil bill procedure followed in the County Courts in this jurisdiction has been remarkably successful in keeping complexity away from these courts. ${ }^{14}$ And the recent innovation of the Certificate of Readiness, under which plaintiffs must be ready to set down a case for trial within six months of filing of a notice of intention to defend, seems to have accomplished much of what a system of judicial case management would be expected to achieve.

None of this means that there is no room for improvement. In particular it is clear that the Certificate of Readiness is not achieving all that it could because delays in the Legal Aid Department have caused many cases not to be ready for trial within six months of the notice of intention to defend. It is also tolerably clear that many cases which settle at the door of the court are listed for hearing quite unnecessarily in the sense that they could have been settled without listing had the parties and their advisers put their minds to it. But the system is clearly achieving enough, and could achieve more without change, to require very good reasons to be advanced to justify significant reform. The Civil Justice Reform Group were correct in their contention that Northern Ireland does not need a Woolf style fasttrack because its County Court system is working very much like a fasttrack already.

In consequence the Group recommended that the central features of the County Court system in Northern Ireland (fixed costs, civil bill procedure, Certificate of Readiness) be preserved. Some proposals for reform were made but these were essentially modest and conservative. First it was recommended that the upper limit on the monetary jurisdiction of the County Court remain at $£ 15,000$, thus synchronising with Lord Woolf's fast-track/multi-track boundary. Within this limit it was proposed that the District Judge's civil bill jurisdiction be raised from $£ 3,000$ to $£ 5,000$ and that the exceptions contained in Order 15, Rule 25(1) of the County Court Rules be abolished. ${ }^{15}$ There should be a more extensive power to remove cases from the County Court to the High Court. This should be upon the motion of the judge as well as the successful application of a party and should be on the grounds, not just of value, but also for reasons of exceptional importance, complexity or public policy. With regard to remittals from the High Court to the County Court the Group was of the view that this should be easier but came to no fixed conclusion as to precise grounds. Fixed times for hearings were considered as a means of ensuring that cases did not have to be adjourned because too many listed cases were contested but this was rejected on grounds of practicality. Finally with respect to appeals the Group recommended that the right to apply for a judicial review be abolished in all cases where there is a right of appeal against a decision of a County Court and that the time limit for all appeals should be 21 days from the decision. However the Group was undecided about that unique feature of the Northern Ireland civil justice

14 On the history and development of the civil bill see D.S. Greer, "The Development of Civil Bill Procedure in Ireland" in J.F. McEldowney and P. O'Higgins (eds), The Common Law Tradition: Essays in Irish Legal History (1990) pp 27-59.

15 These are the same as for the Small Claims Court. See n 5 above. 
system, the appeal by way of complete rehearing from the County Court to the High Court.

The monetary limits on the jurisdiction of the County Court and the District Judge's civil bill list are logically the first of these proposals to consider. So much more successful is the County Court than the High Court in processing cases quickly that it must have been tempting to recommend an extension of the County Court's upper limit beyond $£ 15,000$. However figures quoted in the Interim Report showing an already dramatic rise in the number of civil bills listed in the County Court and corresponding fall in the number of cases set down for trial in the High Court suggest that the distribution of business between these courts is reasonably sensible ${ }^{16}$ unless one takes the position that the High Court should generally stop handling ordinary Queen's Bench work. Raising the monetary limit of the District Judge's civil bill list is more problematic. While this might make the career of a District Judge more interesting and thus aid recruitment to a bench from which County Court judges might be recruited in future, it was somewhat disturbing that the Interim Report presented no figures or analysis of any impact this increase might have on the volume of business handled by District Judges. They will hardly lose much if the monetary limit of the Small Claims Court is increased as this just requires the same persons to determine the same disputes wearing a different hat. But a $£ 3,000$ to $£ 5,000$ jump in the civil bill list might put considerable pressure on lists in the District Judges' courts and on the District Judges themselves. When the sensible proposal to abolish the excepted categories of proceedings is added it should become reasonably clear that this is a proposal needing further thought.

Removal of proceedings from County Court to High Court and remittal from High Court to County Court raise very difficult issues. The easiest one is whether the County Court should have the power proposed to remove cases to the High Court on grounds of importance, complexity or public policy. It seems reasonably clear that this would be a worthwhile power with which to invest the County Court. Removal or remittal on grounds of value alone requires deeper reflection. The author is in possession of anecdotal information to the effect that County Court decrees for sums exceeding $£ 10,000$ are relatively rare. This, allied to the Interim Report's information that approximately $40 \%$ of High Court settlements are within the County Court range, strongly suggests that where a case appears to be worth a five figure sum proceedings are almost invariably issued in the High Court to avoid being trapped by the $£ 15,000$ cap. If, as the author believes, it is worth utilising the County Court rather more whilst preserving the $£ 15,000$ symmetry with the Woolf fast-track, the objective should be to remove the penalty for issuing in the lower court. The penalty can be avoided at present by seeking removal to the High Court but that involves losing the speed and informality of County Court proceedings. Hence a way forward might lie in only permitting removal where a case was obviously worth more than $£ 15,000$ and providing further that an application to remove would permit the County Court judge to award more than $£ 15,000$ and costs on the High Court scale if the case were genuinely of High Court value. To reinforce this move it should further be provided that cases can be remitted from the High Court to the County Court where there is any reasonable prospect that the case could be worth less than $£ 15,000$, again with the proviso that the County

16 At para 2.21 of the Interim Report it is stated that the number of civil bills and ejectments in the County Court has risen from 5,311 in 1992 to 11,094 in 1997, while the number of cases set down for trial in the High Court has declined from 5,610 to 1,749 in the same period. 
Court can award what it thinks the case is worth with High Court costs if appropriate. To some extent these ideas may undermine the $£ 15,000$ boundary between the County Court and the High Court but this boundary should be our slave and not our master. It can work flexibly as a means of distributing business between the two courts without the need for a procedural judge to allocate proceedings between courts based on a range of factors, case value being only one of them.

One of the unsatisfactory features of County Court litigation is the frequency with which cases settle at the door of the court when they really should have been settled long before. Every practitioner will be familiar with court lists which occasionally collapse completely or almost collapse, leaving the judge with unanticipated time on his hands which might have been used eroding a backlog of other cases. It might be very good for barristers who earn brief fees on cases where their services might not have been needed but it causes delay for clients even if it is on nothing like the English scale. Another problem which this causes is that court lists are made very long to ensure that judges have something to do even when a lot of cases do settle. Unfortunately this may mean that when very few cases settle at the court door, others have to be adjourned to another day or the parties settle unwillingly to avoid the inconvenience of having to come back to court. Set times for hearings were rightly rejected because they would only make this problem worse. Fewer cases would be listed per day and collapsed lists would cause further delays in the system. Probably the only way of tackling this problem would be through a system of judicial case management which might succeed in concentrating parties' minds earlier than the day of the hearing but there are other problems with case management which will be discussed below in connection with the High Court. Overall it is clear that the County Court is working reasonably successfully without case management and a system which is not broken does not need to be fixed.

With regard to appeals it seems sensible to dispense with judicial review as an unnecessary duplication where a right of appeal exists. It also makes sense to standardise time limits for appeals at 21 days for both rehearings and cases stated for the opinion of the Court of Appeal. The most difficult issue here is whether to preserve the existing right of appeal by way of complete rehearing to the High Court. This right has existed ever since the establishment of the Supreme Court of Judicature in Ireland in 1877 but has no parallel in England and Wales where appeals from the County Court lie to the Court of Appeal and are essentially confined to issues of law. The author would prefer that the current appellate process remain in place. It provides a valuable safeguard whilst preserving the essential strengths of our County Court system, namely speed and informality. If there were only an English appellate process, County Court judges might have to take more copious notes of evidence, stenographers and tape recording equipment might be needed to prepare transcripts of proceedings, and the whole process would probably be slowed down and rendered more expensive. The Interim Report's figures on the number of such appeals set down for trial between 1993 and 1997 ranges from under $3 \%$ to more than $10 \%$ of cases entered for hearing before the County Courts in any year, with the success rate of appeals running at about $60 \% .{ }^{17}$ The author considers that these figures support the view that County Courts are getting it right first time often enough that this right of appeal should be no cause for concern.

\footnotetext{
17 Interim Report, para 8.70.
} 


\section{THE HIGH COURT}

It is quite clear that the Northern Ireland High Court has not been troubled by problems of cost, complexity and delay to anything like the same extent as the equivalent institution in England and Wales. But problems do abound and a reading of the Interim Report clearly reveals that the Civil Justice Reform Group considered that the High Court was not functioning anything like as well as the Small Claims Court or the County Court.

Complexity is the easiest problem to deal with. Complex litigation is fairly rare in Northern Ireland and the procedure for handling ordinary cases, although it possesses features like pleadings and discovery which are capable of causing complexity, usually operates in a relatively informal manner. Apart from the additional paperwork, running a High Court personal injury case is not markedly more difficult than a civil bill. Chancery actions and cases in the Commercial List are more complex by nature but there are insufficient of these to cause any large scale problem and the case management systems in place for these actions seem to be working reasonably well.

Delay is a more serious problem. Although not as bad as England and Wales it is still routinely taking four years in Northern Ireland to process an ordinary personal injury case. This causes anxiety for individual litigants, deprives them of compensation in the period following the accident when they most need it, ${ }^{18}$ and can be exploited by insurance companies to secure settlements favourable to themselves. ${ }^{19}$ It may also contribute to litigation proving more expensive than it really needs to be. Anyone familiar with the long corridor in the Royal Courts of Justice knows that every morning a substantial amount of personal injury litigation is resolved after a few minutes haggling between counsel on both sides. This does not just look bad for the reputation of lawyers, the courts, and the law in general, it strongly suggests that much litigation could be resolved far earlier than the "door of the court" if only the parties' legal advisers had put their minds to it. It is difficult to escape the conclusion that a great many cases are set down for trial when they were never likely to be tried in the first place and that in consequence a great deal of preparatory work is unnecessarily done. The precise impact this has on costs is difficult to assess. Taxation proceeds on the basis of hourly rates and the Belfast Solicitors' Association and Comerton scales, in contrast to the County Court scales, provide for additional remuneration when cases are settled at later stages. To the extent that this makes late settlements more expensive it may have more to do with the incentives provided by the remuneration process than the phenomenon of late settlements themselves. The problem of costs will be addressed further below.

18 See B. Bryant, R. Mayou and S. Lloyd-Bostock, "Compensation Claims following Road Accidents: a six-year follow-up study" (1997) 37 Med. Sc. Law 326.

19 As Professor Genn found, offers were often delayed until the last minute when the defendant would offer to settle for a sum both substantial from the plaintiff's point of view and also at substantial discount on full value. See H. Genn, Hard Bargaining: Out of Court Settlement in Personal Injury Actions (Oxford, Clarendon Press, 1988); H. Genn, "Access to Just Settlements: The Case of Medical Negligence" in A.A.S. Zuckerman \& R. Cranston, Reform of Civil Procedure (Oxford, Clarendon Press, 1995) p393. 
The Woolf solution to delay was judicial case management. Hearings before procedural judges would establish timetables for taking the necessary steps to prepare cases for trial, would prevent unnecessary interlocutory proceedings and other kinds of procedural skirmishing, and might concentrate the minds of parties and their advisers at an earlier stage so that earlier settlement might be promoted. This system was rejected for Northern Ireland on two quite sensible grounds. First, it was pointed out that most High Court cases settled anyway so that case management would only "front load" and increase costs unnecessarily. Secondly, additional expense would be incurred in terms of judicial training and additional court staff. ${ }^{20}$ Instead of judicial case management the Group proposed that a modified version of the County Court's Certificate of Readiness be introduced, under which the parties would have to be ready to set down a case for trial within nine months of the filing of a defence. This can be supported on the grounds that it would be cheaper than judicial case management, it has worked well enough in the County Court to deserve a chance in the High Court, and that independent studies show that one of the most effective ways of ensuring quick case processing is to set an early date for trial and stick to it. ${ }^{21}$ However if the professions cannot make this system work they may well find that judicial case management is something they have to learn to live with. It does have potential to deliver earlier settlement by concentrating the minds of the parties before they reach the door of the court, the benefits of this arguably outweighing any additional costs.

With regard to costs the current position is broadly that High Court costs can be assessed in two different ways. The usual way is in accordance with informal scale costs set by the Belfast Solicitors' Association for solicitors, and for barristers there is a separate scale known as the Comerton scale. Like the County Court scales, these scales provide for professional fees varying with the amount recovered or defended, although there are important differences from the County Court scales which will be discussed below. For pleadings and interlocutory proceedings fixed fees are laid down by the Taxing Master. The other way is to apply to the Taxing Master for taxation of costs, in which case costs are assessed on hourly rates as opposed to fixed scales. ${ }^{22}$

Fixed scale costs are one of the strengths of the Northern Ireland civil justice system. They make the cost of litigation more predictable than it has been in England and Wales, and almost invariably make it less expensive too. They operate on a "swings and roundabouts" 23 principle, that is for some cases lawyers will be underpaid for a lot of work but for others they can earn generous scale fees without excessive effort. In principle the Group's proposal to give the Belfast Solicitors' Association and Comerton scales statutory force like the County Court scales is to be

20 See C. Menkel-Meadow, "Will Managed Care give us Access to Justice?", in R. Smith (ed) Achieving Civil Justice: Appropriate Dispute Resolution for the 1990s (1996, Legal Action Group, London) pp 94-100.

21 Ibid. See also G. Hoon, "Modernising Civil Justice" (1998) Nottingham Law Journal 10 at p15, where research carried out by the RAND Corporation is referred to.

22 See Donaldson v Eastern Health and Social Services Board [1997] NI 232; E. McMenamin, "To Tax or Not to Tax? That is the Question!" The Writ, Issue No. 90 (April 1998).

23 The County Court scale costs were so described by Carswell LCJ in In the matter of $C \& H$ Jefferson, a firm and In the matter of the Solicitors (Northern Ireland) Order 1976 (judgment delivered 30th October 1998). 
welcomed as enhancing the drive towards controlling costs. However there are curious features of both scales which are worthy of comment.

The Belfast Solicitors' Association scale provides for scale costs for settlement after issue of a writ, which are approximately $60 \%$ of those for settlement after entry in the warned list, and a sliding scale for settlement at various stages in between. The County Court scales are tied to the amount in dispute and are generally unaffected by the stage of proceedings at which a case settles. What is questionable about the sliding scale is that it may offer solicitors an incentive to progress cases on to a later stage to earn a higher fee, when this may not be in the client's best interests. ${ }^{24}$ Like taxation, based as it is on hourly rates, it also represents a detraction from the principle of payment by results as opposed to payment for work done, whether or not any benefit for the client is gained. Other professionals, notably insolvency practitioners, are now having to get used to justifying their remuneration in terms of results as opposed to work done or billable hours. ${ }^{25}$

The Comerton scale does not possess these features to anything like the same extent. Thus fees are only $10 \%$ higher if the case is listed for hearing than if counsel is instructed in early negotiations, and there is also only a very modest difference in scale fees where liability is admitted as compared with when it is denied. The question raised by this scale is why barristers are instructed to do work which does not obviously call for the services of an advocate. Does it follow from the specific provision made for early negotiations and quantum only cases that barristers are "carrying" solicitors through stages of litigation which one might expect solicitors to be able to handle themselves? Is it possible that the large number of very small firms in Northern Ireland means that some litigation practitioners do not have the expertise or the confidence to take cases through to settlement themselves? Is this having an adverse impact upon the costs of litigation by employing two professionals when one might do? $\mathrm{Or}$ is this keeping litigation costs down by enabling solicitors and barristers to make easy money out of "settlers" to compensate for "working their socks off" in those rare cases which go to trial? Does this scale promote settlement ${ }^{26}$ and thereby keep litigation costs lower in this jurisdiction than they have been in England and Wales?

\section{THE CONDUCT OF LITIGATION}

This section covers a variety of topics dealing with the conduct of litigation before and after proceedings are issued. These topics relate both to the County Court and the High Court but are of much greater importance in connection with the latter.

\section{(a) Pre-action protocols}

The Woolf reforms in England and Wales have led to the introduction of a template, known as pre-action protocols, for the conduct of negotiations prior to the issue of proceedings. They cover matters such as the exchange of information between the parties, gathering evidence through discovery

24 On this and costs' rules generally see G. Bevan, P. Fenn and N. Rickman, Contracting for Legal Services with Different Cost Rules (LCD Research Series No. 3/98, March 1998)

25 See the Report of the Working Party on the Remuneration of Office-holders and certain related matters, chaired by Mr Justice Ferris (Lord Chancellor's Department, July 1998).

26 For the case against settlement see O.M. Fiss, "Against Settlement" (1984) 93 Yale Law Journal 1073. 
without issuing proceedings, and the engagement of expert witnesses. They can be very detailed and prescriptive and are clearly designed to feed into the system of judicial case management. However there is no reason to suppose that they are unworkable without judicial case management and, subject to the cautionary notes sounded below, might be worth trying in Northern Ireland as a way of promoting earlier settlement. Although the County Court and the High Court in Northern Ireland have been able to process civil business faster than in England and Wales, the County Court much faster, there are still a great many cases where proceedings are issued and hearing dates arranged unnecessarily. Pre-action protocols, although they could be expensive and could front-load costs in cases which would settle without them, might be able to prevent the unnecessary costs of issuing proceedings and listing for hearing in those very same cases, as well as produce an earlier resolution. They might also give the parties a healthy steer towards Alternative Dispute Resolution, about which more will be said below, before attitudes harden too much for this to have any real chance of success.

\section{(b) Pleadings}

The function of pleadings is to set out each party's case in summary form, so as to crystallise issues for trial and inform the conduct of pre-trial negotiations. They have never been a feature of County Court litigation in Northern Ireland and were rightly rejected for that forum on the basis that they could add nothing to a system functioning very well without them. They have been used in High Court litigation, and in this jurisdiction the former Minister of State's description of English pleadings as "some of the most uninformative documents that human genius is capable of producing" 27 applies with no less force. It is difficult to disagree with the Group's proposal that pleadings be drafted in conformity with the principles undergirding the Civil Procedure Rules 1998, but in the absence of a procedural judge to impose discipline upon the parties it is very difficult to see how this requirement could be enforced. The proposal to replace the writ and statement of claim for plaintiffs, and the acknowledgement of service and defence for defendants, with a claim form and a defence, can be supported on the basis that if we are stuck with uninformative documents a reduction in their number is preferable. However too much should not be made of pleadings. They may not be doing much good but they are not doing much harm either. They do not prevent trials from running satisfactorily and are not the prime cause of late settlement.

\section{(c) Witness statements}

Except for the more complex proceedings in the Chancery Division and the Commercial List, witness statements are not used and exchanged in civil cases in Northern Ireland. This may surprise English readers but it is a product of the relative lack of complexity of civil litigation in this jurisdiction. The experience with witness statements in England and Wales renders it inadvisable, as the Group acknowledged, to introduce witness statements on any larger scale to Northern Ireland. What has happened in England is that a lot of time and effort has gone into drafting witness statements to make them foolproof support for the party on whose behalf they are tendered. So whatever is gained in terms of clarifying the issues is lost in terms of expense. In fact it is questionable whether witness statements do make a major contribution to clarifying issues

27 G. Hoon, "Modernising Civil Justice" (1998) Nottingham Law Journal 10 at p11. 
because the effort put into getting them "right" renders them less like the statements of witnesses and more like elaborate pleadings. It is also doubtful whether they shorten trials by reducing examination in chief because their prior exchange enables counsel to prepare protracted crossexamination. Witness statements have no contribution to make to solving the problem of late settlement.

A related issue is the exchange of witness names. Here the recommendation of the Civil Justice Reform Group, that provision for this should not be made, was a little perplexing. The Group believed that this would lead to the intimidation of witnesses, but disclosure of witness names by the prosecution in criminal cases is mandatory, and the problem of intimidation is arguably more serious there.

\section{(d) Discovery}

In England and Wales everybody seems to agree that there is too much discovery. Either the plaintiff applies for more than it can reasonably use or the defendant throws in everything including the kitchen sink in an attempt to overwhelm the plaintiff or answer any claim that it has not come clean. Whether this problem is replicated in Northern Ireland to any extent, there is nothing in the Interim Report capable of solving it. For the High Court there is the proposal to adopt the principles of discovery enshrined in the Civil Procedure Rules 1998, but these are largely a restatement of traditional principles which obviously did nothing to prevent abuse. What might prevent abuse in England and Wales is judicial case management but this is not going to apply in Northern Ireland. For the County Court the principles applying in the High Court will also apply and there are a series of detailed procedural steps proposed as well. It is not immediately obvious why these are necessary, the best explanation for them probably being that a prominent member of the Group (the learned Recorder of Belfast) thought they were desirable.

\section{(e) Settlement offers}

In a system designed to promote earlier settlement it is clearly important that a party should be able to make a settlement offer which will cost the other party dearly if it rejects the offer unreasonably. At present the only effective way of doing this is through a payment into court, which is limited in two respects. First, it is limited to paying money; and secondly, only a defendant can take advantage of it. There is the alternative of making a "Calderbank" 28 offer to settle "without prejudice save as to costs" but this really only applies where payments into court cannot be made. ${ }^{29}$ The Group's proposal to allow any party to make a settlement offer and to reinforce this with costs or interest penalties where the party rejecting the offer does worse at trial is therefore to be welcomed. It makes sense to allow these offers to be made before, as well as after, the issue of proceedings, and it is also right that they should not be made after a case has been set down for trial. Making such offers at that time would only encourage brinkmanship, which is one of the features of the current system which reform needs to stamp out. ${ }^{30}$ Since the objective of these proposals is to prevent parties unreasonably prolonging litigation, it might be better if a further provision were made that a party subject to a costs or interest penalty be permitted to apply for relief on the ground that it did not unreasonably refuse the offer of settlement. If this were provided for,

28 See Calderbank v Calderbank [1975] 3 All ER 333.

29 See Cutts v Head [1984] Ch 290.

30 See the Genn research referred to at $\mathrm{n} 19$ above. 
it almost goes without saying that the excuse would have to be a very good one.

\section{(f) Summary judgment}

In a High Court case a plaintiff can apply for summary judgment under Rules of the Supreme Court (NI) 1980 Order 14 if the defendant has no viable defence to the plaintiff's claim. The defendant has a much more restricted right to apply under Order 18 Rule 19 to strike out the plaintiff's statement of claim on the ground that it discloses no reasonable cause of action. In the County Court there is no real summary judgment procedure at all. A summary civil bill may be issued in respect of a claim for a liquidated amount and an ordinary civil bill, to which the defendant enters no defence, may proceed as an undefended case before the District Judge on a separate hearing date from defended civil bills. The proposal to adopt the rule in the Civil Procedure Rules 1998, that summary judgment can be granted in either the High Court or the County Court against any party which has no realistic chance of winning, is clearly welcome although the Interim Report does not make clear why this proposal is not simply to replace all existing rules having similar effect.

\section{(g) Expert witnesses}

Broadly speaking, expert witnesses give evidence either on matters of quantum or on issues of liability. Some give evidence on both but this is a relatively rare occurrence.

Those experts whose evidence relates mainly to quantum are usually medical experts, giving reports and testimony about the extent and seriousness of a plaintiff's personal injuries. Only in medical negligence cases would expert medical evidence often relate to issues of liability. In the County Courts in Northern Ireland it is rare for oral evidence to be given by medical practitioners. Before the County Court's monetary limit was raised from $£ 5,000$ the practice was for medical reports to be agreed and handed to the judge for perusal at the commencement of the hearing. Often the defendant did not even instruct a medical expert of its own, reserving any argument about the plaintiff's injuries to comment upon the plaintiff's medical reports. After the increase in the monetary limit of the County Court to $£ 15,000$, defendants started instructing medical experts more frequently and oral evidence became more common. However it was quickly realised that the latter was simply impracticable because of the understandable unwillingness of medical practitioners to leave their surgeries to attend a County Court. The former practice of agreed reports and comment has been restored. In the High Court the practice has usually been for medical experts to attend court and this has caused considerable delay in listing cases because a day has to be found which suits the experts as well as the parties and their advisers. Given the frequency with which cases settle close to the hearing or at the door of the court, this often turns out to be unnecessary delay. Hence the Group was correct to recommend that expert medical evidence relating to quantum should normally come in the form of written reports, and that oral evidence should only be allowed with the leave of the court or the consent of all parties. For those cases where oral evidence is needed the proposal for a telephone conferencing system should be developed as a possible means of reducing delay and cutting costs.

Experts whose evidence goes to liability, for example consulting engineers, present more difficult issues. The Group clearly had the perception that some experts were "hired guns" for either plaintiffs or 
defendants and there is a reference to courts being faced with "clearly biased professional witnesses". ${ }^{31}$ Whatever the extent of this problem, expert witnesses are sufficiently vital to establishing liability that the potential for abuse undoubtedly exists. It would neither be correct in principle nor practicable for there to be a court appointed expert witness for individual cases. Such persons could become too much like an arm of the judicial authority, effectively deciding some cases themselves, and would lead to parties appointing their own experts to provide material to challenge adverse findings. The better ways forward are, as the Group proposed, for experts to present their evidence in the form of written reports and only to be allowed to give oral evidence with the leave of the court or the agreement of all parties. Another proposal with the potential to curb abuse is the one encouraging expert witnesses to meet and discuss points of difference with a view to presenting a joint report. Whether or not they can achieve this, reports must be shared with other parties. These proposals are probably as far as one can go to control the use of expert witnesses without resorting to judicial case management. In the absence of the latter all the court could do would be to impose costs orders against, for example, the use of unnecessary expert witnesses, and the effectiveness of this step may well be blunted by a party's ability to pay and the need to ensure that unfair hindsight judgments were not made.

\section{CIVIL JUSTICE POLICY}

It is proposed to examine two subjects in this section - how Alternative Dispute Resolution (ADR) might be developed as a suitable alternative to conventional litigation, and the development of civil justice policy through the Civil Procedure Rules Committee and the Civil Justice Council.

\section{(a) Alternative Dispute Resolution}

There is virtually no ADR infrastructure in Northern Ireland. Mediation is hardly used in family cases, the Commercial List offers no stay or adjournment for ADR treatment and no early neutral evaluation, and there is nothing like the mediation scheme for personal injury cases that operated in the Central London County Court from May 1996 until March $1998 .^{32}$ The only formal alternative to trial is the procedure operating in the Chancery Division whereby a case can be adjourned for four weeks to give the parties an opportunity to explore settlement themselves. The vast majority of civil cases in Northern Ireland settle out of court but they settle through a process of "litigotiation", in which legal proceedings are issued and the parties then bargain in the shadow of the law, often resolving the dispute a short or very short time before the case is due to be heard.

The Civil Justice Reform Group suggested that the legal profession should embrace ADR much more whole heartedly than it does at present, and it did make a number of more concrete proposals which are useful as far as they go. Thus the Group proposed that pilot mediation schemes should be established in medical negligence and commercial cases. Judges would have power to order a stay of proceedings to give the parties an opportunity to consider ADR but the reference would only occur if all parties consented to it. Long term study of ADR would be a matter for the Civil Justice Council which will be discussed below. These proposals, useful though they undoubtedly are, reveal a very narrow vision of what ADR is about. Essentially the Group saw ADR as another form of "litigotiation", this time with the intervention of a third party. The Group

31 Interim Report, paragraph 10.63.

32 On this see H. Genn, The Central London County Court Pilot Mediation Scheme: Evaluation Report (LCD Research Services No. 5/98). 
did not conceive of ADR as being something to resort to before legal proceedings are issued, as an attempt to resolve disputes without the pretence that the case is going to be tried. If ADR is going to make a significant contribution to the earlier and generally more satisfactory resolution of disputes, the period prior to the issue of proceedings is the one where a difference can be made. After the issue of proceedings is often too late; parties' attitudes have hardened by then and do not soften until the hearing is imminent. This is the challenge for ADR in the future and this is the kind of development which the Civil Justice Council should try to stimulate.

Of course ADR may not succeed in producing an earlier settlement and where a settlement is produced there would be no way of knowing whether one would not have been produced anyway. In either case further costs might be incurred and the argument could be made that this is of no benefit to a system where the vast majority of cases do not require a judicial determination. However this would be a short sighted view of the future of civil justice and it is not one which the Group was adopting. The bottom line is that consumers of dispute resolution services deserve a choice of methods of obtaining justice. ADR might be more expensive, especially if it does not succeed, but where it does succeed it will probably be quicker and should be considerably pleasanter than the present adversarial process. It should be encouraged by those who have power to encourage its development, and if clients do not buy into it, it can be abandoned on the basis that "litigotiation" is what people prefer.

\section{(b) The Development of Civil Justice Policy}

Looking to the future the Group recommended the formation of two committees, similar to those now established in England and Wales, which would have responsibility for developing civil justice policy. A Civil Procedure Rules Committee would have responsibility for drafting and maintaining rules of civil procedure to be used in the Northern Ireland courts. Its membership might be composed of eight judicial officers, four to six practitioners, and two or three others who could be members of the Northern Ireland Court Service or others with experience of the workings of the civil justice system. The equivalent committee in England and Wales has a membership composed of six judicial officers, six practitioners (defined so as to include persons like legal civil servants), one person with knowledge and experience of consumer affairs, and another drawn from the lay advice sector. The other committee to be established is the Civil Justice Council. Its responsibilities would include taking forward the proposals of the Civil Justice Reform Group, keeping the civil justice system under review, advising the Lord Chancellor upon the development of the civil justice system, and commissioning research into matters affecting the system. Given the absence of much research into the operation of the civil justice system in Northern Ireland this last role would be of great importance. ${ }^{33}$ The Council's membership would consist of six judicial officers, four practising lawyers, two members of the Northern Ireland Court Service, and four to six other persons from persons with knowledge of consumer affairs, the advice sector, legal academia, or litigant representation. The equivalent English body has very similar responsibilities and similar membership, although persons with

33 On the value of research into civil justice policy see R. Cranston, "The Relational Study of Law", in A.A.S. Zuckerman \& R. Cranston (ed.), Reform of Civil Procedure - Essays on "Access to Justice" (Clarendon Press, Oxford, 1995) pp 31-59. 
experience of consumer affairs, the lay advice sector and litigant representation are listed as separate categories.

One of the first tasks of the new committees would be to consider whether Northern Ireland needs to retain separate rules of procedure for the County Court and the High Court or whether a unified body of Civil Procedure Rules would be desirable. If the civil bill procedure is to be retained, as the Group recommended, a degree of divergence will be inevitable but it would still be possible to have unified rules with some adaptations for the County Court.

Two main criticisms may be made of the Group's proposals with regard to these committees. The first is that they are very lawyer dominated, more so than the equivalent English committees. The Civil Procedure Rules Committee probably should be lawyer dominated because much of its work will be technical but it is not even proposed that there should be any persons who can speak for consumers or litigants. As the Civil Justice Council is concerned with policy matters it should preferably have a 50-50 split in membership between lawyers and non-lawyers. A marked contrast is provided by the proposed Legal Services Commission for Northern Ireland, to take over the operation of the Legal Aid scheme in this jurisdiction. As proposed its membership will be lay dominated, with lawyers not even certain to have any membership at all. ${ }^{34}$

The other criticism to be made of these committees is that the relationship between them is not clearly defined. There is to be some overlap in their membership but the status of each and their responsibilities vis-à-vis the other are nowhere stated. The preferred relationship, it is submitted, is for the Civil Justice Council, as the policy making body, to be the senior committee which should have the power to delegate responsibility for implementing proposals to the Civil Procedure Rules Committee. Even though the latter would be the junior committee, it should be able to act on its own initiative with regard to rule changes, especially in relation to technical matters. However in respect of more substantive policy questions it should refer to the Civil Justice Council for a view before proceeding to make new rules itself.

\section{CONCLUSION}

The Northern Ireland civil justice system shares some of the problems of the former English system although not to the same degree. The Civil Justice Reform Group's proposals draw on English reforms to some degree but many of the most important tenets of Lord Woolf's report are either rejected or adapted to reconcile them with current Northern Ireland practice. To this extent Woolf is kept from the door rather more than welcomed to cross the threshold.

The Small Claims Court would remain essentially the same as it is now with a relatively modest increase in its upper monetary limit. Neither of the other big features of the English Small Claims Court, personal injury cases and road traffic accidents, are strongly supported. The County Court retains its separate procedure and very much lower monetary limit, and no big push is given towards abolition of the distinctive Irish right of appeal by way of rehearing to the High Court. In the High Court judicial case management is almost completely rejected, the Certificate of Readiness

34 See Public Benefit and the Public Purse - Legal Aid Reform in Northern Ireland (consultation paper issued by the Northern Ireland Court Service, June 1999). 
system proposed being grounded essentially on principles of party autonomy. Witness statements are also rejected and even some of the Woolf reforms which are accepted, such as those relating to pleadings and discovery, are not likely to produce any real change in the absence of case management.

The overall approach taken by the Civil Justice Reform Group is to be welcomed. It consists of examining the Northern Ireland system itself, to ascertain its own strengths and weaknesses, and to prescribe solutions for Northern Ireland based upon an understanding of the problems here. It is very much to be hoped than when reforms to that other pillar of the justice system, the Legal Aid scheme, are undertaken, that they will be guided by the same considerations. 